\title{
Imagens de uma Outra Modernidade: Gilberto Freyre e o espaço-tempo latino-americano'
}

Sergio B. F. Tavolaro²

\section{Resumo}

Tempo e espaço são duas categorias fundamentais no programa intelectual de Gilberto Freyre. Sem perder de vista sua produção mais conhecida e celebrada voltada à compreensão da formação brasileira, o presente artigo almeja identificar os sentidos e conotações que o autor confere a ambas as noções em suas reflexões a respeito do lugar e importância da América Latina no concerto da modernidade. Conforme pretendo mostrar, a seu ver, o tempo-espaço latino-americano não poderia de modo algum ser reduzido ao das chamadas sociedades modernas centrais, seja no plano conceitual, seja em sua dimensão de experiência prática, o que em boa medida ajudaria a explicar formas de sociabilidade marcadamente distintas num e noutro contextos. Por fim, pretendo investigar a existência de eventuais convergências entre essas preocupações de Freyre e algumas abordagens contemporâneas no seio da teoria sociológica.

Palavras-chave: Modernidade. Gilberto Freyre. Teoria sociológica. Pensamento social brasileiro.

Do encontro, interpenetração e simbiose envolvendo culturas táo diversas e variadas quanto a ameríndia, a dos negros da África e a dos latinos da Europa, asseverou Gilberto Freyre em certa ocasião, teriam resultado "novos tipos de relaçóes entre grupos humanos e em atitudes do Homem para com a Natureza, para com o Espaço e para o Tempo que já podem ser consideradas atitudes especificamente latino-americanas." (FREYRE, 2003, p. 33) A bem

I Este artigo resulta de uma pesquisa que se beneficia de apoio do CNPq (Bolsa Produtividade). Os argumentos aqui desenvolvidos foram apresentados em uma primeira versão no XVII Congresso Brasileiro de Sociologia (2015), no GT 34 Teoria Sociológica. Agradeço pelos comentários e sugestões então recebidos bem como por ocasião da submissão deste trabalho à revista Política \& Sociedade.

2 Professor Adjunto do Departamento de Sociologia e do Programa de Pós-Graduação em Sociologia da Universidade de Brasilia (UnB). Bolsista Pesquisador ID CNPq. 
da verdade, tempo e espaço são duas categorias do entendimento fundamentais em seu programa intelectual. Sua vasta e multifacetada obra interpretativa acerca da formaçáo social brasileira remete-se de maneira profusa e extensa a ambas as noçóes para avançar a tese de que a nossa seria uma sociedade marcada por peculiaridades iniludíveis, um quadro societário único e especial na modernidade (FREYRE, 2004; FREYRE, 2000a; FREYRE, 2000b; FREYRE, 1990; FREYRE, 1976; FREYRE, 1973b; FREYRE, 1941). Como bem sabemos, para o autor pernambucano, haveria aqui outros sentidos de tempo, assim como tipos de espaço distintos daqueles observados entre as sociedades da Europa setentrional (ARAÚJO, 1994; BASTOS, 2006; BURKE; PALLARES-BURKE, 2009; LARRETA; GIUCCI, 2007; SANTOS, 2008; TAVOLARO, 2013; VILLAS BÔAS, 2006).

O presente artigo almeja abordar esse importante aspecto da fatura freyreana. Mas em vez de retomar seu tratamento da singularidade brasileira, interessa-me outro tema, a meu ver também merecedor de atenção: suas proposiçóes em torno da pretensa peculiaridade societal latino-americana. Em verdade, ao se debruçar sobre essa questáo, Freyre fez valer uma longa tradição do pensamento brasileiro, uma agenda de preocupaçáo que o precedera e que prosseguiria para além dele - qual seja, as alardeadas especificidades do subcontinente, bem como o lugar do Brasil nessa experiência. Eis, pois, a primeira questão que move o artigo: sem perder de vista sua produção mais conhecida e celebrada voltada à compreensão da formação brasileira, qual enquadramento interpretativo Freyre confere à América Latina ao também posicioná-la no concerto da modernidade? Associada a essa questáo, um segundo problema entretém o artigo: quais os sentidos e conotaçóes das noçóes de tempo e espaço nessas reflexóes de Freyre a respeito da experiência latino-americana?

Abundam evidências de que, tal como em sua obra dedicada à compreensão da formaçáo brasileira, tempo e espaço serviram a Freyre não apenas como suporte para argumentar que a América Latina representava uma importante novidade em relação às configuraçôes sociais hegemônicas do Ocidente. De fato, em inúmeras ocasiôes, conforme sugerido pela produção já acumulada a esse respeito (BASTOS, 1998a; BAGGIO, 2012; CRESPO, 2003; FREITAS, 2013; SCHNEIDER, 2012; VALENTE, 2013), o autor manifestou seu desconforto diante do que percebia ser uma tendência bastante generalizada: tomar aquelas configuraçóes ocidentais como padróes de medida exclusivos e 
inequívocos para outros cenários, dentre os quais a própria América Latina. Ora, como pretendo reforçar, a seu ver, o tempo-espaço latino-americano náo poderia de modo algum ser reduzido ao daquelas sociedades - seja no plano conceitual, seja em sua dimensão de experiência prática -, o que em boa medida ajudaria a explicar formas de sociabilidade marcadamente distintas num e noutro contextos. Isso posto, é minha intenção revisitar a hipótese de acordo com a qual Freyre ambicionava mostrar que, ao invés de sinais de sua incompletude na modernidade, as peculiaridades espaço-temporais da América Latina seriam elas mesmas expressóes de seu protagonismo no quadro social contemporâneo, capazes inclusive de apontar para alternativas a alguns dos impasses e esgotamentos das ditas "sociedades centrais". Nesse sentido, longe de um mero ensaio imperfeito da civilização moderna, a América Latina representaria uma realização própria, bem sucedida e até mesmo modelar em alguns aspectos.

Por fim, eis a terceira questão que orienta o artigo: qual o alcance e vigor dessas proposiçóes de Freyre? Seriam elas presas de seu próprio horizonte intelectual? Ou haveria alguma consonância com elaboraçóes mais recentes no seio das ciências sociais? A meu ver, preocupaçóes análogas às do autor animam algumas abordagens contemporâneas que se propóem interpelar criticamente o imaginário sociológico da modernidade. Refiro-me, nesse particular, a quatro programas de reflexão: a abordagem das modernidades múltiplas, o programa da modernidade global, formulaçóes em torno da condição pós-colonial, e o programa da decolonialidade do saber/poder. Conforme minha hipótese, a retórica de Gilberto Freyre em seus trabalhos e reflexóes devotados à América Latina aproxima-se de alguns dos pontos das agendas dessas formulaçóes críticas à sociologia da modernidade. Por certo, não se trata de programas plenamente convergentes. Suas interpelaçóes àquele imaginário demonstram graus distintos de escopo e profundidade: em alguns casos, o objetivo é adequá-lo à maior variedade de configuraçóes societárias que se seguiu ao alcance ampliado da modernidade (modernidades múltiplas e modernidade global); em outro extremo, ambiciona-se uma ruptura mais radical com aquele discurso (condição pós-colonial), quando não sua superação em favor de uma nova epistemologia (decolonialidade do saber/poder). Admitidas suas irredutíveis diferenças, ainda assim parece haver um denominador comum a essas abordagens: a problematização daquele imaginário, de suas categorias e noçóes, de suas unidades de análise, de suas ambiçóes universalistas, do escopo 
empírico de aplicação almejado, assim como de suas insinuações prescritivas. Se é que existem tais consonâncias entre Freyre e esse debate contemporâneo, entáo pode-se tomá-las como indicativas de que ao menos algumas de suas proposições a respeito da "questão latino-americana" foram capazes de resistir ao teste do tempo.

Além deste introito (I), o artigo subdivide-se em outras cinco partes: (II) chamarei atenção para certa presença da América Latina em reflexóes do pensamento social brasileiro que precederam os trabalhos de Freyre; (III) contemplarei a fortuna crítica a respeito de suas elaboraçóes em torno da experiência societária latino-americana; (IV) abordarei como Freyre retrata as peculiaridades históricas e sociais da América Latina bem como suas diferenças em relação à América anglo-saxônica e à Europa setentrional; (V) tratarei dos sentidos e conotaçóes conferidos por Freyre ao tempo-espaço latino-americano, contemplando alguns de seus comentadores a respeito desse tema; e, por fim, (VI) farei consideraçóes acerca do alcance e vigor das propostas interpretativas do autor à luz de proposiçóes contemporâneas.

\section{II}

Antes de Freyre, é evidente, um conjunto expressivo de intérpretes brasileiros debruçou-se sobre a América Latina, sobre sua identidade e lugar no concerto da "civilização ocidental". Sabemos que o século XIX foi pródigo de imagens que ajudaram a sedimentar fronteiras claras entre a "América Anglo-saxônica" e a "América Latina" (FERES JR., 2005; MIGNOLO, 2005). Uma profunda fenda gradativamente abria-se entre uma secção e outra do continente. Inúmeros predicados (associados aos seus atributos físico-naturais, às suas composiçóes raciais, às suas culturas, histórias, economias, instituiçôes, dentre outros) eram apontados como provas cabais da cisão entre ambas - e, ato contínuo, como explicação das distintas trajetórias, realizações e insucessos de cada uma das partes ${ }^{3}$. Nesse contexto, aos poucos, a América Latina passou a ser um objeto de preocupação mais recorrente também entre

3 As observações de Hegel a esse respeito, na "Introdução" de Filosofia da História, são certamente emblemáticas desse cenário. Segundo o autor, "Comparando a América do Sul (contando o México como parte dela) com a América do Norte, observamos um espantoso contraste". Para ele, "Na América do Norte testemunhamos um estado de coisas próspero [...]. Na América do Sul, ao contrário, as repúblicas dependem somente da força militar [...]." (HEGEL, 1956, p. 83-84). 
nossos intelectuais e homens públicos. Note-se, porém, conforme Leslie Bethell (2009) já teve oportunidade de advertir, que por algum tempo tais reflexóes ecoaram certa desconfiança de políticos, intelectuais e historiadores hispano-americanos quanto ao pertencimento do Brasil à categoria "América Latina”: pretensas especificidades (geográficas, além daquelas relacionadas a fatores econômicos, culturais, institucionais, históricos, linguísticos, dentre outros) responderiam por suas singularidades em relação aos vizinhos da América espanhola. São muitas as obras e intervençóes públicas do final do século XIX e início do seguinte expressivas dessas tensóes (ver, por exemplo, LIMA, 2010). Deixe-me revisitar ao menos três intérpretes cujas posiçóes são sugestivas das diferentes matizes que coloriam tal cizânia ${ }^{4}$. Ainda que de modo algum esgotem o debate, de certa forma (BETHEL, 2009), essas três posiçóes antecipam alguns dos problemas e formulaçóes de Gilberto Freyre a respeito da "questão latino-americana".

Na última década do século XIX, no libelo $A$ ilusão americana (1894), Eduardo Prado descartava qualquer esperança de fraternidade entre os Estados Unidos e a América Latina. Para ele, fatos históricos não faltavam para atestar os desacertos entre as duas regióes, por si só reveladores do frequente desprezo estadunidense pelos caminhos e descaminhos das sociedades latino-americanas. Com pesar, Prado argumentava que a tendência dos países da América espanhola havia sido imitar "as fórmulas norte-americanas", em detrimento das "tradiçôes de sua raça e da sua história”. A seu ver, graças às suas inconfundíveis diferenças, o resultado desse transplante de leis e modelos institucionais provocara invariavelmente um estado de "artificialismo político", acompanhado de "exotismo legislativo" (PRADO, 1957, p. 45). Afinal, para ele, tratava-se de duas raças ímpares - sendo a saxônica a "mais enérgica da espécie humana" -, habitantes de ambientes naturais igualmente desiguais em força, poder e riqueza - também nesse caso em favor dos norte-americanos.

No entendimento de Eduardo Prado, esse divórcio entre as duas secçóes do continente se aplicaria, da mesma forma, ao Brasil: a distância do país em relação à "grande república anglo-saxônica" decorreria de aspectos

4 Leslie Bethell (2009, p. 301-302) observa que, "Durante a Primeira República, os principais intelectuais brasileiros - entre eles, Eduardo Prado, Manuel de Oliveira Lima, Joaquim Nabuco, Euclides da Cunha, Manoel Bomfim - tinham ideias bastante diferentes em relação aos Estados Unidos e ao pan-americanismo"; a meu ver, isto também é um reflexo de suas distintas percepções acerca das identidades latino-americana e brasileira. 
geográficos, mas também "pela raça, pela religião, pela índole, pela língua, pela história e pelas tradiçóes do nosso povo." (PRADO, 1957, p. 7). A bem da verdade, nem mesmo a alardeada irmandade do Brasil em relação a seus vizinhos latinos parecia-lhe convincente: "separados deles pela diversidade da origem e da língua [...] nem o Brasil físico, nem o Brasil moral formam um sistema com aquelas naçóes" (PRADO, 1957, p. 10) ${ }^{5}$. Se as próprias naçôes ibéricas da América viviam às turras entre si, a confraternização entre as duas partes do continente parecia-lhe uma ordem de acontecimentos no mínimo improvável ${ }^{6}$.

É verdade que em contraste com Eduardo Prado, ao tornar-se embaixador do Brasil em Washington nos primeiros anos do século XX, Joaquim Nabuco passou a defender de maneira veemente a opção do país e do continente por uma política pan-americanista. Parecia-lhe esta uma estratégia eficaz para resguardar a região frente às investidas imperialistas da Europa. Mesmo assim, suas intervençôes públicas elogiosas à Doutrina Monroe não apagavam a certeza quanto às diferenças que identificava entre as duas secções da América, a seu ver habitadas por populaçóes, crenças, índoles e hábitos inteiramente diversos (NABUCO, 2010a, p. 309). Sendo distintos os seus ritmos - o Norte veloz, o Sul mais lento - suas realizaçóes não poderiam ter sido as mesmas (Nabuco, 2010c). Não por outra razão, Nabuco afastava qualquer temor quanto à eventual absorção estadunidense de territórios latino-americanos, afirmando que isso "causaria um profundo desequilíbrio em seu sistema de governo e uma incalculável deterioraçáo de sua raça" (NABUCO, 2010a, p. 309). Portanto, conquanto tomasse a América Latina e os EUA como parceiros naturais - "membros de uma única família entre as naçóes" (NABUCO, 2010c, p. 557) - contra uma Europa beligerante, a parcela mais significativa da "contribuição do Novo Mundo para o bem-estar da humanidade" parecia-lhe vir dos Estados Unidos (com destaque para a força da imigração voluntária na formação da pátria, a democracia, a igualdade de condiçóes sociais, e o sistema de educação) (NABUCO, 2010b, p. 532 e demais).

5 Não surpreende, pois, a resistência de Prado à opção republicana em 1889, "o mesmo grande erro em que os hispano-americanos tinham caído": a adoção artificial de uma "fórmula norte-americana", ou ainda, de "instituições de uma raça estranha" (PRADO, 1957, p. 46).

6 Leslie Bethell (2009: 303-304) indica que Euclides da Cunha, tanto quanto José Veríssimo, demonstrava pessimismo similar a respeito da relação do Brasil com os demais países do subcontinente - embora para Veríssimo os brasileiros também fossem um povo hispano-americano. 
Uma terceira posição ilustrativa daquela polêmica pode ser encontrada na interpretação de Manoel Bomfim. Por um lado, A América Latina: males de origem (1905) aproxima-se de Nabuco ao reafirmar a existência de uma identidade latino-americana clara, lastreada em um passado comum que remontaria às especificidades históricas da Península Ibérica. Ao mesmo tempo, porém, sua interpretaçáo converge com a apreciaçáo de Eduardo Prado ao adotar uma postura reticente diante das imagens depreciativas e difamatórias que, na visão de Bomfim, eram comumente projetadas sobre a América Latina. Nesse exato sentido, o autor argumenta que "como de costume, sempre que se trata das repúblicas latino-americanas, os doutores e publicistas da política mundial se limitam a lavrar sentenças - invariáveis e condenatórias. A ouvi-los, não há salvação possível para tais nacionalidades." (BOMFIM, 1993, p. 38). Analista arrojado, Bomfim rechaçava explicaçóes do atraso latino-americano apoiadas sobre a pretensa inferioridade de suas raças; tais teorias não passariam de "um sofisma abjeto do egoísmo humano, [...] covardemente aplicado à exploração dos fracos pelos fortes." (BOMFIM, 1993, p. 243). Mas esse esboço de crítica epistemológica não o demovia totalmente da opiniáo de que "os povos sul-americanos se apresentam, hoje, num estado que mal lhes dá direito a ser considerados povos civilizados" (BOMFIM, 1993, p. 49). Sem embargo, divergindo de opinióes correntes à sua época, a ousadia de sua interpretação estava em afirmar que os problemas da América do Sul derivavam "exclusivamente das condições históricas da colonização" (BOMFIM, 1993, p. 261), razáo pela qual se deveria priorizar o estudo das "condiçóes sociais e políticas" desses povos (BOMFIM, 1993, p. 54).

A “geração de 1930" não passaria incólume a essas preocupaçóes ${ }^{7}$. Para nos restringirmos a apenas dois casos célebres, vale lembrar que em Raizes do Brasil (1936), Sergio B. de Holanda ancora a formaçáo brasileira em heranças culturais ibéricas. Espécie de "zona fronteiriça, de transição" em relação às formas de convívio e instituiçóes que desaguariam na modernidade europeia, os déficits de "racionalização da vida" observados entre espanhóis e portugueses - sua "aversáo congênita a qualquer ordenação impessoal da existência" (HOLANDA, 1994, p. 75) -, somados a certa "cultura da personalidade",

7 A tomar pela produção de intelectuais como Celso Furtado, Darcy Ribeiro, Florestan Fernandes, Fernando H. Cardoso, Octavio lanni, dentre outros intérpretes do Brasil, é óbvio que tal agenda de reflexão claramente se prolongou no pensamento brasileiro para além de Gilberto Freyre. 
que por sua vez parecia-lhe ser "o traço mais decisivo na evolução da gente hispânica" (HOLANDA, 1994, p. 4), deixariam marcas indeléveis em suas aventuras colonizadoras na América. Vale frisar, em seu entendimento, todas essas características teriam adquirido cores ainda mais vivazes na cultura do colonizador português, a mais decisiva na peculiar formação brasileira.

Por seu turno, Caio Prado Jr. sublinha a existência de duas áreas do continente americano nas quais a colonizaçáo teria assumido contornos muito distintos. Enquanto na zona temperada o mote principal da colonização teria sido a ocorrência de "lutas político-religiosas, que desviam para a América as atençôes de populaçóes que não se sentem à vontade e vão procurar ali abrigo e paz para suas convicçóes" (PRADO Jr., 2011, p. 22-23), nas regióes tropical e subtropical, o sentido primordial haveria de ser a exploração comercial pura e simples das riquezas naturais e gêneros do território. Estariam aí as raízes dos diferentes destinos de cada uma no correr dos séculos: naquela se constituiria uma sociedade com "semelhança pronunciada à do continente de onde se origina” - a Europa (PRADO JR., 2011, p. 23-24). Nestas, surgiria "um tipo de sociedade inteiramente original", resultado de "um rumo inteiramente diverso do de suas irmãs da zona temperada." (PRADO JR., 2011, p. 27-28).

Em certa medida, pode-se dizer que Gilberto Freyre foi tocado por preocupaçôes análogas a essas de seus colegas de geração. Mas, quiçá mais que Buarque de Holanda e Prado Jr., Freyre reviveu as tensóes que alimentaram os debates encenados por intelectuais e homens públicos brasileiros da virada do século XIX para o XX. Conforme buscarei salientar, por um lado, seus escritos comungam de certas expectativas pan-americanistas já observadas nas intervençóes públicas de Nabuco. Ademais, o aproximam de Eduardo Prado e Oliveira Lima ao sublinhar a especificidade brasileira no contexto latino-americano. Ao mesmo tempo, convergem com Manoel Bomfim ao também representarem certo esforço de revisão epistemológica, que o conduz, inclusive, a formular críticas contumazes a uma compreensão estrita do pan-americanismo (FREYRE, 2003c, P. 49-50) ${ }^{8}$. Por fim, Freyre parece

8 Freyre adverte que "A palaura pan-americanismo se desenvolveu como uma espécie de glorificação da ideia de massa ou totalidade americana, que é sem dúvida alguma uma força que deve ser aproveitada pelos estadistas americanos, mas pela qual não devemos deixar dominar como por um gigante apenas forte" (FREYRE, 2003c, p. 49). A seu ver, "A uma Pan-América indistinta, pomposamente maciça, filipicamente una, me parece preferivel uma combinação interamericana de energias regionais e qualidades provinciais [...]" (FREYRE, 2003c, p. 49-50). 
compartilhar com todos da tendência de colocar em relevo a peculiaridade da América Latina em contraste com a América do Norte bem como com a Europa setentrional.

\section{III}

Nenhuma outra preocupação possui tamanha importância e visibilidade no programa intelectual de Gilberto Freyre como a busca pela compreensáo da formação social brasileira. Isso é fato. Suas obras consideradas mais seminais, produzidas ao longo de um período que para muitos foi de fertilidade sem igual, são predominantemente orientadas por essa preocupação, que sem sombra de dúvidas o marcaria de uma vez por todas (ARAÚJO, 1994; BASTOS, 2006; SOUZA, 2000). Ocorre que, embora "mais lembrado por um só livro", Freyre foi táo prolífico e versátil quanto "amplo em seus interesses" (BURKE; PALLARES-BURKE, 2009, p. 77). Um dos quais, tal como outros obscurecidos por aquela agenda, é a identidade da América Latina no concerto da "civilização ocidental". Várias de suas reflexôes a esse respeito, produzidas nos anos iniciais da década de 1940 (BAGGIO, 2012; LARRETA; GIUCCI, 2003), mas revisitadas por Freyre em momentos posteriores, revelam um autor igualmente disposto a interpelar o imaginário da modernidade.

Recentemente, maior atenção tem sido dirigida a essa faceta de sua obra - a qual, talvez valha a pena já sublinhar, insinuava-se desde seus trabalhos devotados à formação brasileira. A esse respeito, alguns aspectos parecem ser salientados de maneira mais incisiva, dentre eles: a) a retomada, a partir de novos ângulos, de suas críticas frequentes à hegemonia (econômica, militar e política, mas também epistemológica, simbólica e cultural) gozada pela Europa setentrional e pela América do Norte; b) as eventuais continuidades e rupturas que esse tópico representa em relação a outras de suas preocupaçóes e a momentos diversos de sua produçáo; c) sua dívida com o universo intelectual hispano (espanhol e latino-americano) do final do século XIX e início do século XX; d) por fim, chama-se atenção para a dimensão discursivo-combativa dessas proposiçôes acerca da identidade latino-americana, definidora de certa agenda política e intelectual de açáo.

No tocante às dívidas intelectuais de Freyre que podem tê-lo informado no tipo de tratamento dedicado à experiência latino-americana, além das influências de autores britânicos denunciadores "do capitalismo industrial, da 
feiura da modernidade" (PALLARES-BURKE, 2005, p. 48-49), salienta-se o sentimento de desconforto e estranhamento que o aproximava de intelectuais espanhóis da virada do século XIX para o XX (BASTOS, 1998a; BASTOS, 1998b), tanto quanto de pensadores e literatos latino-americanos das primeiras décadas do século passado (CRESPO, 2003), também eles insatisfeitos com a adoção automática do modelo civilizatório europeu e norte-americano como padrão de medida universal (BURKE; PALLARES-BURKE, 2009; SCHNEIDER, 2012). A empatia de Freyre com esses universos intelectuais variados decorreria de certa homologia de seus contextos sociais, comumente retratos em descompasso (cultural, econômico, político, comportamental, institucional, natural, estético etc.) com relação aos centros mais dinâmicos da modernidade, como sendo lugares, gentes e culturas híbridos entre Ocidente e Oriente e ainda sob o impacto decisivo do tradicional e do arcaico. Daí a valorizaçáo do local, de suas irredutíveis peculiaridades, acompanhada do esforço de relativização dos "critérios de subordinação cultural e ideológica implícitos nas visóes geradas a partir das correntes europeias" (CRESPO, 2003, p. 185). Nesse exato sentido, fala-se da notável presença de Unamuno, Azorin, Pio Baroja, Ganivet, dentre outros intelectuais da célebre "geração espanhola de 98", assim como de Ortega y Gasset, Américo Castro e outros nomes fundamentais da "geração de 14" na obra de Freyre (BASTOS, 1998b; BAGGIO, 2012), - fontes de sua noção de "tempo tríbio", assim como de sua preocupação com as relaçóes entre o Ocidente e o Oriente, o tradicional/ arcaico e o moderno, os europeus e os não europeus. Fala-se, ainda, de seus diálogos e dos empréstimos de ideias formuladas por pensadores e homens públicos latino-americanos do porte de José Enrique Rodó, José Vasconcelos, Alfonso Reyes e Fernando Ortiz (CRESPO, 2003; VALENTE, 2013). Tais referências, argumenta-se, ajudaram a modelar sua própria compreensão acerca das especificidades e potencialidades da América Latina no quadro da modernidade contemporânea.

No que diz respeito ao lugar dessas preocupaçóes no conjunto da obra do autor pernambucano, por um lado, afirma-se que muitos dos insights que orientaram sua interpretação da formação brasileira moldaram suas elaboraçóes em torno da experiência latino-americana - dentre eles as pretensas raízes náo exclusivamente ou totalmente europeias, que jamais teriam deixado de se fazer presentes em ambos os casos, além de sua defesa e celebração da tradição e do hibridismo cultural e racial dessas sociedades (BASTOS, 1998a; 
BAGGIO, 2012; LARRETA; GIUCCI, 2003; VALENTE, 2013). Ao mesmo tempo, sublinha-se os pesos diversos da influência intelectual hispânica em sua vasta e multifacetada obra (BASTOS, 1998b), assim como a variedade de tratamentos dessa agenda, ora distanciando, outras vezes aproximando o Brasil das demais sociedades latino-americanas (FREITAS, 2013).

Por fim, a respeito da dimensão crítica e política dessas reflexóes, bem à altura das ambiguidades que lhe eram táo características, sugere-se que, por um lado, elas revelam um autor decidido a denunciar os olhares eurocêntricos projetados sobre o Brasil e a América Latina (CRESPO, 2003; BURKE; PALLARES-BURKES, 2009), dono de uma obra "crítica à modernidade ocidental” (SCHNEIDER, 2012, p. 77), mas também flagrantemente idílico em seu afã de elevar a experiência tropical americana à condição de "alternativa civilizatória” à modernidade carbonífera (BAGGIO, 2012, p. 120). Ou seja, Freyre com alguma frequência teria combinado elogios indisfarçados aos predicados da experiência latino-americana - vários deles bastante questionáveis - a primorosas reflexôes acerca dos descaminhos e impasses das sociedades modernas centrais, de seu sentido de tempo bem como do teor de suas relaçôes com sociedades e culturas periféricas. Por outro lado, revelam também um homem disposto a oferecer apoio intelectual ao regime autoritário e colonialista de Salazar (SCHNEIDER, 2012), além de cético em relação à adequação da democracia política e dos princípios liberais - "soberania popular, sufrágio universal, cidadania” - ao Brasil e à América Ibérica (BAGGIO, 2012, p. 128).

\section{IV}

Afinal, "Que é, na verdade, em suas relações com outras partes do mundo, a América de ordinário denominada Latina?” (FREYRE, 2003a, p. 17). Em resposta a essa indagaçáo, Freyre contemplou aspectos e problemas os mais variados. É certo que a ênfase maior de seu programa intelectual permaneceu por muito tempo perscrutar, explicar e compreender a formaçáo brasileira, vislumbrada como uma experiência verdadeiramente única. "A primeira sociedade moderna constituída nos trópicos com característicos nacionais e qualidades de permanência" (FREYRE, 2000a, p. 86) teria resultado de uma combinação ímpar de fatores, narrados com inconfundível vivacidade em Casa-grande \& senzala (1933), Sobrados e mucambos (1936), Nordeste (1937), 
além de outros trabalhos. Conduzida por uma estirpe de europeus situada a meio caminho da África, já habituada ao intercurso sexual e cultural com povos de outros continentes - a seu ver, graças a condiçóes ambientais prévias que lhes dotaram de inigualável plasticidade para lidar com circunstâncias inusitadas -, o empreendimento colonizador português na América teria se fortalecido com o influxo de outras culturas e predicados biológicos; ao invés de empecilhos à nossa formação, africanos e indígenas teriam lhe facilitado ainda mais a instalação em áreas tropicais, por vezes pródigas, outras tantas inóspitas a europeus incautos e desprovidos das mesmas qualidades. $\mathrm{O}$ resultado dessa empresa em nada ortodoxa é retratado por Freyre com rara expressividade: um "equilíbrio de antagonismos" (FREYRE, 2000a, p. 125)", leia-se, uma experiência social "enriquecida de um lado pela espontaneidade, pelo frescor de imaginação e emoção do grande número e, de outro, pelo contato, através das elites, com a ciência, com a técnica e com o pensamento adiantado da Europa" - verdadeira "fusão harmoniosa de tradições diversas." (FREYRE, 2000a, p. 123). Tudo isso, cabe uma vez mais ressaltar, num ambiente tropical marcado por " $[\mathrm{g}]$ randes excessos e grandes deficiências" (FREYRE, 2000a, p. 89). Em linhas gerais, esse mesmo enquadramento lhe serviria de amparo para retratar a experiência latino-americana.

Reconhecido o peso dessa problemática na fatura freyreana, conforme salientei há pouco, seria incorreto tomá-la por exclusiva. É certo que em Interpretaçáo do Brasil (1945), talvez bem ao gosto de um Eduardo Prado, o leitor é uma vez mais remetido a características que responderiam pela especificidade da América portuguesa em relação à espanhola, à francesa e à anglo-saxônica ${ }^{10}$. Nessa direçáo, Freyre retoma várias das ideias anteriormente introduzidas em Casa-grande \& senzala, ilustrativas de nossa constituição supostamente única. Apesar disso, conforme observado por Freitas (2013), já

9 Pallares-Burke (2005, p. 4I) alerta-nos para as raizes intelectuais inglesas dessa expressão: Thomas Carlyle e Herbert Spencer.

10 Num artigo de jornal de 1942 - "Americanismo e hispanismo" -. Freyre argumentava que o brasileiro representava um "povo americano de formação sociológica singular - com a preponderância do português $e$ a larga participação do negro e a rápida valorização do mestiço - e de formação política igualmente singular - considerado o longo periodo monárquico que nos marcou o caráter, talvez para sempre [...]" (FREYRE, 2003d, p. 92). Ao mesmo tempo, porém, defenderia posteriormente "ser o Brasil, embora de origem principalmente portuguesa, duplamente hispânica, tendo sua formação se processado durante os dias coloniais, não só sob influência portuguesa como sob uma considerável orientação da Espanha" (FREYRE, 1975a, p. XLIX) Dai sua objeção àqueles que queriam erguer "uma como que barreira entre o Brasil [...] e a América Espanhola." (idem). 
aparecem ali sugestóes de uma pretensa comunhão latino-americana: alude-se a um passado compartilhado pelos "povos hispânicos", retratado em Casa-grande \& senzala como "condiçôes de meio físico, de situação geográfica, de desenvolvimento histórico" (FREYRE, 2000a, p. 314). Ao fim e ao cabo, ambos Portugal e Espanha se mostrariam sociedades situadas "entre dois climas, dois tipos de solo e de vegetação, duas raças, duas culturas, duas concepçóes de vida, dois complexos ecológicos [...]." (FREYRE, 2001, p. 59); por essas e por outras, jamais teriam se revelado experiências ortodoxa e puramente europeias (BASTOS, 1998a). Ou seja, embora naquelas obras da década de 1930, Freyre chegasse a falar de especificidades irredutíveis nas experiências colonizadoras de portugueses e espanhóis (2000a, p. 161-163), já se prenunciava o argumento do parentesco de primeiro grau entre o Brasil e as demais sociedades latino-americanas, enfatizado em trabalhos posteriores. Assim é que, em Interpretaçáo do Brasil, parecia a Freyre que do ponto de vista da "ecologia vegetal ou animal", bem como de sua "ecologia humana", a América Latina poderia ser considerada um continente à parte, distinto da América anglo-saxônica (FREYRE, 2001, p. 264-265).

Nos escritos dedicados de maneira prioritária à América Latina, tais apreciações assumem tom mais contundente. É verdade que menções são feitas a uma identidade supostamente compartilhada por todo o continente: Freyre chega a referir-se à "solidariedade básica, física, ecológica com a América anglo-saxônica", segundo ele acompanhada de certo "clima social americano" diverso do Europeu, posto que caracterizado pela tensão entre forças de rotina (os americanos já estabilizados) e renovaçáo (os imigrantes), pretensamente comum às duas secçóes do continente (FREYRE, 2003a, p. 19). Ao mesmo tempo, porém, o autor volta a defender a existência de uma "cultura hispânica" específica - enriquecida por ampla variedade de elementos a princípio díspares - próprios a Portugal e Espanha, remontando ao passado da Península Ibérica (FREYRE, 2000b, p. 72). Essa "cultura hispânica" compreenderia "valores simbólicos e irracionais" distintos até mesmo "dos valores racionais de outros latinos, como os franceses e os italianos, neste particular herdeiros mais diretos da tradição greco-romana [...]" (FREYRE, 2003a, p. 25-26) ${ }^{11}$.

II Em O brasileiro entre os outros hispanos, dirá Freyre que "a Europa ibérica ou hispânica apresenta uma Europa, em grande parte, tropicalizada [...]. Tropicalizada nos sangues e na aparência de suas gentes, na sua arquitetura, na sua música, nas suas danças, nas suas vozes, nos seus gestos, nos seus risos, nos seus andares, nos seus cultos religiosos, nos seus doces, nos seus quitutes." (FREYRE, 1975a, p. 85). 
Uma vez mais, a seu ver, aquele passado comungado por Espanha e Portugal teria se prolongado em suas empresas colonizadoras ${ }^{12}$, resultando em "inconfundíveis semelhanças sociológicas de comportamento e de cultura" por exemplo, "entre um caboclo brasileiro assimilado à cultura luso-católica e um mexicano assimilado à cultura espanhola católica [...]" (FREYRE, 2003a, p. 21). Tais semelhanças se traduziriam num "conjunto de atitudes do homem em face da natureza e da sociedade" - derivadas de uma dada interpretaçáo latina do cristianismo, "mais plástica que a anglo-saxônica" (FREYRE, 2003a, p. 21). Pilar básico dessa "latinidade", haveria um "ethos supranacional ou estilo latino-americano", envolvendo certo tipo de comportamento político, de atividade econômica, de estilos de convivência social, tanto quanto expressóes literárias, musicais, lúdicas, coreográficas, científicas e culinárias similares nas diversas áreas da América Latina (FREYRE, 2003a, p. 26 e 33-34) ${ }^{13}$. Fossem elas expressóes porto-riquenhas, venezuelanas, haitianas, brasileiras ou paraguaias, todas teriam se beneficiado das "interpenetraçóes entre valores latinos e americanos, entre valores eruditos e primitivos, entre valores católicos e animistas, entre valores europeus ou afro-ameríndios [...]", em notório contraste com o padrão de convivência observado "na América ocupada por anglo-saxóes" (FREYRE, 2003a, p. 28-29). Essa apreciação, é claro, não lhe impedia de identificar diversidades - ou como gostava de dizer, de "ilhas sociológicas", "em oposição à sua continentalidade magnificamente cenográfica" (FREYRE, 2003c, p. 48) Reconhecida tal variedade, ainda assim, dizia Freyre que "O espaço americano e o tempo hispânico seriam aspectos de uma só vivência, de uma única experiência, do mesmo processo de desenvolvimento de vários grupos humanos de comum origem européia em terras americanas [...]." (FREYRE, 1975a, p. 110).

$\mathrm{Na}$ verdade, essas formulaçóes flertavam com outra pronunciada preocupação, que já havia entretido geraçóes de intelectuais que o precederam:

12 Freyre argumenta inclusive que "a interpenetração entre as duas principais subculturas que formam a hispânica - a castelhana e a portuguesa, para não nos referirmos a outras - foi tal, que tanto a presença espanhola se fez sentir, mais de uma vez, de modo intenso, na colonização portuguesa de várias daquelas sub-regiões tropicais do domínio tropical lusitano, como o contrário também se verificou: a presença portuguesa se fez notar na colonização espanhola de áreas tropicais" (FREYRE, 1975a, p. 76).

13 Diria ainda que "Somos, os brasileiros, uma gente hispânica sendo também uma gente situada no trópico e localizada na América: duas outras dimensões de espaço-tempo que nos condicionam, além da cultura, o ETHOS [...]" (FREYRE, 1973b, p. 8). 
as tensões envolvendo a América Latina e a Anglo-saxônica. Nesse aspecto, de um lado, há um Freyre notoriamente crítico que, já na década de 1940, manifestava-se preocupado com certo pan-americanismo homogeneizante, desatento às peculiaridades internas do continente (FREYRE, 2003c, p. 49). Posteriormente, em Novo Mundo nos Trópicos, Freyre acabaria por denunciar, à la Manoel Bomfim, "certa tendência, entre uns tantos americanos, para usar depreciativamente a expressão 'latino-americano', sob a impressão de que nas Américas tudo aquilo que é latino seja sempre inferior ao anglo-saxão ou nórdico (FREYRE, 2000b, p. 261). Seria esse um sinal da dificuldade para se admitir que "povos largamente nãoeuropeus em sua composição étnica e na parte folclórica da sua cultura" pudessem "crescer como um conjunto de civilizaçóes modernas; e em se organizarem como naçóes de tipo moderno em espaços semi ou totalmente tropicais" (FREYRE, 2000b, p. 266). A seu ver, apreciaçóes depreciativas como essas decorreriam do fato de certos povos se considerarem "biológica, cultural e totalmente superiores aos subeuropeus que encontravam em ambientes náo-europeus, e, sob seu ponto de vista, completamente inferiores - física e culturalmente inferiores." (FREYRE, 2000b, p. 267).

Mas, ao lado disso, havia também um Freyre pan-americansista, que preferia frisar as complementaridades e interpendências das duas partes do continente $\mathrm{e}^{14}$. À la Joaquim Nabuco, reclamava esforços de aproximação mútua, "uma política continental combinada em que a variedade prevaleça sobre a preocupaçáo de excessiva uniformidade." (FREYRE, 2001, p. 264-265). Nessa direção, defendia "uma política cultural em dois sentidos [...] entre as duas Américas, com a apreciação recíproca de valores e invençóes latinos e anglo-americanas" (FREYRE, 2000b, p. 261). Afinal, a seu ver, "também os norte-americanos poderiam receber da América Latina proveitosos exemplos e sugestóes, em lugar de adotar a rígida atitude de quem, pelo fato de ser líder do progresso industrial, julga que é, ou deve ser, o líder absoluto de tudo na cultura hemisférica e que a América do Sul deve seguir seu exemplo em todas as atividades humanas ou culturais." (FREYRE, 2000b, p. 260-261). Seria preciso, pois, reconhecer as qualidades regionais e provinciais do continente, incentivando utilizá-las "interamericanamente" (FREYRE, 2003c, p. 49-50).

14 Para o autor, "o aspecto étnico da democracia" desenvolvido pelos "latinos", combinado ao aspecto político aprofundado pelos "anglo-saxões", seria um bom exemplo dessa articulação (FREYRE, 200I, p. 270). 
Está claro que, de maneira análoga à sua interpretação da formação brasileira, ao se debruçar sobre as peculiaridades atribuídas à América Latina, Freyre preferia ressaltar os êxitos dos esforços de implantação de uma civilizaçáo moderna em espaços e ambientes naturais diversos dos da Europa setentrional e da América do Norte. A inversão dos sinais da avaliação sociológica é evidente: vários dos predicados comumente tomados como responsáveis pelo atraso e pelos descaminhos da América Latina - clima, solo, flora, miscigenação racial, catolicismo, predomínio da vida rural, patriarcalismo, tradicionalismo, hibridez cultural, fluidez social, dentre outros - são apontados como ingredientes do sucesso dos povos latino-americanos; de uma maneira ou de outra, todos esses ingredientes teriam lhes dotado de inigualável competência para erigir sociedades e culturas portentosas em circunstâncias e ambientes muitas vezes adversos aos padróes de vida da modernidade inaugurada pelos norte-europeus. Tivessem sido outros os envolvidos, provavelmente a empresa colonizadora não haveria de prosperar com o mesmo êxito e vigor.

O que se pode destilar dessas reflexóes é sua tentativa de reivindicar para a América Latina dose expressiva de protagonismo na modernidade. Identificadas as especificidades dessas sociedades, tratava-se de desmontar os estigmas que via de regra recaíam sobre elas, reconhecendo contribuiçóes por muito tempo ofuscadas ou distorcidas - quando náo de todo invisibilizadas - pelo etnocentrismo norte-europeu e anglo-americano. Trazidos à luz seus valores positivos, conforme salientarei adiante, tais peculiaridades poderiam inclusive tornar-se referências para alguns dos dilemas contemporâneos enfrentados pelas próprias sociedades ocidentais hegemônicas. Bem-sucedido ou não em seus resultados, Freyre almejava realizar um exercício de crítica política e epistemológica ao que percebia serem padróes de medida por demais estritos para contemplar as novidades da América Latina ${ }^{15}$. Na mesma direção de algumas propostas mais recentes no seio da teoria social, tal desiderato levou-o a questionar o universalismo que certas experiências societárias pretendiam não só para suas formas de vida e organização como também para suas categorias cognitivas, padróes normativos e referências estético-expressivas. Conforme pretendo mostrar, esse impulso crítico está no cerne do tratamento que Freyre devota às categorias tempo e espaço.

15 Nesse exato sentido, Freyre lamentava o que via como a "sentença de morte sociológica para parte considerável da América chamada Latina” [...]” (FREYRE, 1975a, p. 28-29). 


\section{V}

Certa ocasião, Gilberto Freyre observou que "povos situados em espaços tropicais, ou nas proximidades desses espaços, parecem desinteressar-se, mais do que os outros, de rigores na contagem do tempo, só atendendo aos extremos de chuva e sol correspondendo a necessidades de alimentação" (FREYRE, 1975a, p. XXXIII). Com efeito, a seu ver, o "sentido de tempo" variava "consideravelmente de regiôes para regiōes", fosse de um continente a outro ou mesmo dentro de um único país, "exprimindo-se em diversas manifestaçôes de existência, de convivência e de cultura" (FREYRE, 1975a, p. XLVI). Parecia-lhe, pois, mais que evidente a importância sociológica a ser devotada aos critérios "genético" e "ecológico"16: entrelaçados, tempo e espaço seriam variáveis imprescindíveis à compreensão de experiências societárias diversas como as de civilizaçóes que, segundo Freyre, vinham "resultando, nas mesmas regióes, do contato com a natureza, com ambiente e com populaçóes e culturas tropicais" (FREYRE, 1968, p. 86-87). Nesses casos, os descompassos com relação à modalidade norte-europeia de modernidade mostravam-se claros.

É verdade que, também nesse caso, tais disjunçôes são igualmente salientadas em suas obras dedicadas à compreensão da formação brasileira. Sobrados e mucambos e Nordeste, por exemplo, são pródigas em passagens nas quais a celebraçáo de nosso passado, bem como da lentidão da vida cotidiana de então, faz-se acompanhar de críticas contumazes aos efeitos (sociais e naturais) advindos da adoçáo do ritmo frenético da modernidade da Europa setentrional (FREYRE, 1996, p. 535-536). Lastimava o autor que esse "novo ritmo se não de produção ou de trabalho, de existência ou de recreaçáo que muitos adquiriram de repente dos europeus do Norte" (FREYRE, 1996, p. 541) vinha não só dissolvendo influências orientais em nossos "modos de viver", formas de convívio e "modos de pensar" (FREYRE, 1996, p. 424) como também

16 A respeito do "critério ecológico de análise sociológica", Freyre chegou a dizer que "O ambiente que interessa ao sociólogo considerar é um conjunto de repercussões inconfundivelmente psicoculturais e socioculturais do que é físico, natural, bioquímico nesse ambiente" (1968, p. 76-77). Já a sociologia genética seria aquela especializada "no estudo das origens e do desenvolvimento no tempo social das instituições, sobretudo, de estilos de vida e de formas de convivência que se tenham tornado características do comportamento de um grupo humano" (FREYRE, 1968, p. 73-74). Por fim, cabe esclarecer que, sob a influência de Ortega y Gasset (BAGGIO, 20I2; BASTOS, 1998b; SCHNEIDER, 20I2), para Freyre, o tempo social é sempre um tempo tríbio, ou seja, envolve o encontro de "três tempos num só": o passado, o presente e o futuro, "como ora um, ora outro, dentre eles, mais dominante, embora nunca exclusivo" (FREYRE, 1968, p. 31). 
provocando impressionantes transformaçóes em nossas paisagens urbanas e rurais. Na maior parte dos casos, tais processos de europeização (modernização) eram lamentados como sinais de degradaçáo de espaços e hábitos outrora muito bem ajustados ao meio tropical (FREYRE, 1996, p. 431; FREYRE, 2004 , p. 178). Ainda assim, a tomar por outros escritos seus, a modernização europeizante que se abateu de maneira mais sistemática sobre o Brasil e demais populaçóes latino-americanas a partir do século XIX - na esteira das investidas imperialistas de ingleses e franceses, posteriormente sob a liderança norte-americana - não teria diluído por completo aquelas práticas e noções alternativas às da Europa do Norte (FREYRE, 1975a, p. XLVIII-XLIX); ademais, ao invés de algo restrito a este ou àquele segmento da população, tais práticas e noçóes teriam sido formadas e cultivadas por cada um dos componentes étnico-raciais chave daquelas sociedades: os ibéricos (espanhóis e portugueses), os ameríndios e os negros africanos.

Asserçôes como essas não passaram despercebidas por seus intérpretes e comentadores. Ao menos nesse particular, talvez o traço com frequência mais salientado seja exatamente o desencontro sugerido pelo autor pernambucano entre as experiências sociais tropicais e a configuraçáo tempo-espacial associada por ele à Europa do norte e à América setentrional. Observa-se que desde jovem, ainda estudante na Universidade de Columbia, Freyre já se referia à "coexistência de diferentes tempos no Brasil do meio do século XIX” (BURKE; PALLARES-BURKE, 2009, p. 271). Em sua visão, o trópico seria justamente um local de intersecção entre o tradicional e o moderno (BASTOS, 2006, p. 152), um espaço de convivência simultânea de temporalidades diversas. Ora, ao conferir expressivo peso ao passado, ao sopesar as "perdas e a sobrevivência do tradicional face ao moderno" (BASTOS, 2006, p. 176), o empreendimento freyreano teria inevitavelmente se posicionado "em flagrante oposição às obras que se baseiam nas concepçóes modernas e progressistas do tempo [...]." (VILLAS-BOAS, 2006, p. 49) Quanto à dimensão espacial, destaca-se sua sensibilidade aguda ao "elemento ecológico" da experiência social, cedo revelada em suas preferências e afinidades com "escritores regionais” brasileiros e estrangeiros (BURKE; PALLARES-BURKE, 2009). Afirma-se que suas remissóes cada vez mais frequentes, seja aos predicados físicos dos trópicos, seja a seus pretensos efeitos sobre as formas de vida humanas (SANTOS, 2008) serviam-lhe para sustentar que os padróes civilizacionais europeus em hipótese alguma poderiam ter sido replicados de maneira pura e 
simples nessas regióes (LARRETA; GIUCCI, 2007). Na caracterização oferecida por Freyre, o ambiente tropical - termo bastante elástico, empregado "para se referir a uma regiáo, o Nordeste; ao Brasil em sua totalidade [...]; e a partes da Ásia, da África e das Américas", por vezes até à Espanha, à França ou mesmo às populaçóes mediterrâneas em geral (BURKE; PALLARES-BURKE, 2009, p. 296) - seria tomado por "excessos", transfigurando condiçóes físicas e geográficas ímpares em padróes culturais igualmente peculiares (ARAÚJO, 1994, p. 58). Enfim, fala-se que, para Freyre, da aventura portuguesa na América florescera uma nova modalidade de civilizaçáo, espécie de "modernidade híbrida e tropical" (LARRETA; GIUCCI, 2007, p. 422-423), tão inusitada quanto única em seus resultados.

A essas interpretaçóes gostaria de acrescentar duas observaçóes iniciais. Primeiramente, nos trabalhos em que nosso autor tratou de maneira mais detida da questáo do espaço-tempo latino-americano, certa estratégia de argumentação é recorrente: ao destacar as alardeadas especificidades da América Latina, com razoável frequência ele o fazia em franco contraste com contextos societários denominados "nórdicos", "Protestantes", ou mesmo "norte-europeus"; tratar-se-ia, a seu ver, de um conjunto de experiências delineadas de maneira bastante diversa daquelas predominantes na "Europa carbonífera, burguesa e Protestante". A estratégia consistia em trazer à lume, dotando de positividade, práticas e representaçôes tempo-espaciais singulares tanto quanto alternativas às experiências da chamada "Europa mais especificamente europeia” (FREYRE, 2010, p. 294). Com isso, Freyre também almejava chamar atenção para outras configuraçôes modernas, caudatárias daquelas práticas e representaçôes espaço-temporais anunciadas como especiais à América Latina. A segunda observação inicial é que na visão do autor, as peculiaridades do espaço-tempo latino-americano resultavam da combinação de um conjunto de elementos por si só extravagante: uma experiência europeia desde pronto singular (já que "impura" em suas origens e manifestaçóes), a cujos horizontes de experiência prática e imagética se misturariam tradiçôes extraeuropeias, com suas formas de sociabilidade e quadros de referência comportamentais e mentais também especiais. Vale observar, para Freyre, importava o fato dessa conjunção algo inusitada de fatores ter ocorrido num ambiente natural muito diverso do europeu do norte assim como do americano setentrional.

Para começar, cabe notar que a Freyre parecia fundamental que a própria civilizaçáo hispânica já demonstrasse um "sentido de tempo", além de 
"preferências por espaços, ou regióes onde expandir-se" diversos daqueles mais característicos da Europa do norte. Seus comportamentos e posturas divergiriam da "rígida atitude anglo-saxônica - 'tempo é dinheiro' - com o culto quase místico dos minutos e até dos segundos, devido ao seu valor prático e comercial" (FREYRE, 2000b, p. 264-265). Esse "tempo cronométrico seguido pelo anglo-saxão como um tempo quase sagrado" seria desprezado pelo hispano, "para quem isso de pontualidade absoluta, regulada pelo relógio ou pelo cronômetro, seria subordinação humilhante do Homem [...] à hora ou ao minuto tirânico" (FREYRE, 1973b, p. 25). Nesse sentido, em flagrante contraste com o "ritmo constantemente progressivo" inaugurado pela Revolução Comercial, a noção hispânica de tempo teimava em fundir e conciliar passado, presente e futuro (FREYRE, 1975a, p. 106-107). Justamente sob esse enquadramento temporal diverso, prevaleceram padróes comportamentais em que "o trabalho e o descanso alternavam muitas vezes, entre esforço e dança, com numerosos dias santos e de festa, concedidos aos fiéis pela própria Igreja" (FREYRE, 1975a, p. 8-9). Oras, ao fazer "do ócio um tempo digno de ser vivido criadoramente" (FREYRE, 1975a, p. XXXVI) - em descompasso com "aqueles norte-europeus e norte-americanos mais impregnados da ética Calvinista, excessivamente glorificada do contínuo, do incessante trabalho humano" (idem) -, o hispano teria se revelado, "de todos os europeus, o que menos sucumbiu à obsessáo de ser o futuro sempre melhor que o presente e o presente melhor que o passado", uma obsessão que, para Freyre, correspondia "ao mito caracteristicamente europeu de Progresso constante e indefinido" (FREYRE, 1975a, p. 69). Para eles, "como para povos nãoeuropeus, em geral", não haveria "fatalidade no Progresso nem na chamada Evolução transposta do plano biológico ao sociológico" (idem). Daí porque, "a certos pretendidos progressos" os hispanos preferissem "regressos ou finca-pés culturais, sociais, morais que signifiquem resistência a alteraçóes consideradas prejudiciais a interesses de sempre" (FREYRE, 1975a, p. 70).

Mas note-se que, embora defendesse a importância desse passado europeu ímpar, em hipótese alguma era desejo de Freyre atribuir-lhe parcela desproporcional de responsabilidade na formaçáo da América Latina, de suas experiências práticas e representaçóes mentais. Em oposição àqueles que decretavam que "a chave de interpretaçáo do ethos e da cultura latino-americana" estava "num latinismo (europeu) rigidamente puro" (FREYRE, 2003a, p. 34) 
- talvez porque essa representasse outra variedade de eurocentrismo -, o autor propunha que a "americanidade", na verdade, encontrava-se profundamente enraizada "à terra americana", isto é, radicada na terra "do homem e da cultura que o europeu de várias origens encontrou já integrados na natureza desta parte do mundo. Principalmente na natureza tropical e semi-tropical da América” (FREYRE, 2003b, p. 38) ${ }^{17}$. Conforme sugeri anteriormente, o que teria havido, na visão do autor, fora uma convergência virtuosa de elementos étnico-raciais e culturais diversos que acabaram entrelaçando-se na América tropical graças a felizes coincidências e afinidades.

Dentre as inúmeras causas apontadas para o sucesso desse encontro, duas merecem destaque. Primeiramente, a noção hispânica de tempo supracitada, a qual tornava esse europeu menos resistente, quando não mais aberto, a intercâmbios com povos e culturas nãoeuropeus (FREYRE, 1975a) ${ }^{18}$. Em segundo lugar, as convergências observadas entre os hispanos e as culturas náoeuropeias (americanas e africanas) em torno das próprias noçóes e experiências espaço-temporais: conforme o autor, na medida em que "a atitude predominante do homem para com o tempo" entre as "civilizaçóes e culturas orientais, africanas e ameríndias" era fortemente "afetada pelo mito, a religião e o folclore", elas também não se viam dominadas "por uma visão científica ou sociológica rigidamente evolucionista", ou mesmo "por um quadro de atividade contínua - 'progressiva', portanto, no sentido convencional da expressão - como índice de progresso histórico [...]" (FREYRE, 1975a, p. 10). Tal "semelhança entre sentidos de tempo dos hispanos e dos náoeuropeus dos trópicos" teria justamente facilitado "no século XVI - o século dos primeiros contactos maiores de hispanos com populaçóes tropicais, principalmente na América - a aproximação entre eles, hispanos, e essas populaçóes tropicais - aproximação dificultada pelo sentido cronométrico dos norte-europeus [...]” (FREYRE,

17 Em evidente contraste com o retrato traçado no capítulo II de Casa-grande $E$ senzala, nos escritos dedicados prioritariamente à América Latina, Freyre passa a cultivar a imagem do "elemento indigena", que parece tornar-se ali emblemático dessa integração moral com a natureza tropical, verdadeiro "lastro social ou de cultura" da "comunidade americana" (FREYRE, 2003, p. 4I), aquele que, em combinação com o elemento hispânico (espanhol e português), veio a constituir a base comum "na formação social e de cultura da grande maioria dos povos americanos" (FREYRE, 2003, p. 42), segundo ele, povos "de formação indo-hispânica" (FREYRE, 2003b, p. 44). A esse respeito, ver Freitas (2013).

18 Diz-nos Freyre que os "espanhóis e os portugueses foram os únicos europeus com influência sobre áreas não europeias que não sublinharam nos seus contatos ou no seu trato com os nãoeuropeus, nem a sua europeidade nem a sua condição de povo progressivo" (FREYRE, 1975a, p. 8). 
1975a, p. XXXIII). Quer nos convencer Freyre que, desde o princípio, esses intercâmbios teriam ocorrido "sem o acelerado de trabalho e de produção que, nos espaços frios e temperados, europeus e americanos, parece ter sido uma expressão da Revolução Industrial e do sistema capitalista de competição econômica [...]" (FREYRE, 1975a, p. 44).

Também nesse caso, os contrastes entre o ibérico e o europeu do norte, assim como suas implicaçóes sociais e ecológicas, são bastante enfatizados pelo autor. A seu ver, desde o início, o colonizador protestante da Europa do norte, ao ver-se diante da natureza tropical, de sua gente e de sua cultura, teria adotado uma postura de superioridade, "aparentemente erudita e ética ou moralmente profilática", apartada "da gente primitiva: das suas culturas e das suas intimidades com as selvas" (FREYRE, 1975a, p. 31-32). Teria sido outro o comportamento do "europeu hispânico e Católico em face da mesma realidade" - conforme nosso autor, náo tão nova a ele, graças a sua proximidade da África tanto quanto à "penetração de grande parte da península hispânica desde dias remotos, por africanos portadores de valores tropicais [...]" (FREYRE, 1975a, p. 31-32). Essa outra atitude, compartilhada por eruditos e gentes comuns, seria caracterizada pela "confraternização com os indígenas, com seus valores de cultura e com a natureza vegetal ou animal de espaços quentes" (FREYRE, 1975a, p. 31-32) - ou seja, uma postura de identificação prática "com a natureza, a vida, a gente, as culturas, deste vasto pedaço de mundo tropical ignorado até então pelos europeus” (FREYRE, 1975a, p. 33).

Em todas essas proposiçóes é indisfarçável a relevância conferida ao espaço tropical, tido por fator condicionante de primeira linha da própria experiência latino-americana. No entendimento de Freyre, o trópico demovia a civilização europeia de sua pureza, "impondo-lhe modificaçóes ou alteraçóes essenciais e às vezes assimilando-a quase por completo ao seu sistema cultural-ecológico [...].” (FREYRE, 1975a, p. 30). Note-se que sua expressa ambição de dissolver essencialismos de cunho biológico e/ou geográfico (e seus correspondentes estigmas) projetados sobre a identidade latino-americana náo o impedia de enquadrar a "americanidade" a um só tempo como "condiçáo sociológica" e "fenômeno ecológico", isto é, "como um perfil novo de cultura no mundo", firmemente assentado sobre valores morais e materiais integrados no espaço natural americano (FREYRE, 2003b, p. 38-39). Ora, admitida a diversidade interna do continente, a identidade comum da porção hispânica da América 
decorreria também do fato desse conjunto de sociedades "integrar-se num mesmo espaço americano" (FREYRE, 1975a, p. 111), leia-se, em "condiçóes tropicais de vida" (FREYRE, 1975a, p. 85-86), nas quais, conforme sugerido em outra ocasiáo, predominariam "relaçóes mais livres e mais íntimas do homem com a natureza, favorecidas pelo clima e pela luz tropicais" (FREYRE, 2010 , p. 193 $)^{19}$. Teria sido justamente nesse espaço tropical, único em muitos aspectos, que o hispano miscigenou-se com populaçóes e culturas "pré-industriais, pré-burguesas e pré-capitalistas", cujos padróes comportamentais e mentais, plenamente ajustados à "ecologia dos trópicos", revelaram-se, à sua maneira, bem-sucedidos em comparação com aqueles dos europeus setentrionais e dos norte-americanos (FREYRE, 1975a, p. 44).

Considerados todos esses fatores, para Freyre, não restavam dúvidas de que as criaçôes políticas, econômicas, administrativas e artísticas da América Latina eram "expressóes de um processo menos de cálculo absoluto que de improvisação gradual" (FREYRE, 1975a, p. 6). Com efeito, a seu ver, tal fato vinha "significando, em muitos casos, o sacrifício da sistematização, do planejamento, da precisão metodológica, da correção artística, a um constante e direto contato do homem criador, através do tempo, com a vida e com a natureza" (FREYRE, 1975a, p. 6) Sem embargo, se equivocariam aqueles para quem essa acomodaçáo ao espaço tropical, acompanhada da recusa ao sentido cronométrico e exato de tempo, havia resultado em reveses, desvantagens e incompatibilidades com a modernidade (FREYRE, 1975a, p. 44-45). $\mathrm{Na}$ verdade, essas experiências vinham produzindo fatos novos e positivos, inclusive "novas formas de conhecimentos" (FREYRE, 1975a, p. 80), isto é, "Novos saberes sobre gentes, animais, plantas, doenças, terapêuticas tropicais. Novas interpretaçóes existenciais e de convivências humanas condicionadas por ecologias tropicais" (FREYRE, 1975a, p. 85-86). Tudo isso indicava a Freyre a existência, nas sociedades latino-americanas, de quadros alternativos

19 Conforme Freyre já havia proposto em Casa-grande E senzala, os meios físico e bioquímico tenderiam a "recriar à sua imagem os individuos que the chegam de várias procedências" (FREYRE, 2000a, p. 48). Tal tendência se manifestaria ou por influência indireta do clima (FREYRE, 2000a, p. 88), ou pela capacidade do meio fisico tropical de amaciar comportamentos e temperamentos (FREYRE, 2004, p. 52), de afrouxar e corromper instituições e formas de cultura outrora rígidas em sua pureza europeia (FREYRE, 2000a, p. 80), ou mesmo de influenciar "o desenvolvimento de formas de arte" que contemplassem as "relações do homem com o meio", isto é, "com o sol, com a luz, com as formas, com as sombras características desse meio ou a ele peculiares" (FREYRE, 2010, p. 186). 
de representação e vivência da própria modernidade. Conforme observarei no próximo item, ao fim e ao cabo, para Freyre, aquele "culto do 'mais ou menos' " (FREYRE, 2000b, p. 264-265), o "sentido relasso" de temporalidade, aquela "resistência passiva e quase exagerada à tirania do relógio sobre a vida" (FREYRE, 1973b, p. 112-113), ou mesmo a menor inclinação "para sacrificar quase-tudo na vida ao progresso coletivo e rápido" (FREYRE, 2001, p. 265) comportamentos esses expressivos de "um modo de pensar, agir, de proceder" mais harmônico com a natureza - poderiam servir de lição e modelo aos "desajustamentos constantes ou frequentes em sociedades civilizadas" (FREYRE, 1973b, p. 113).

\section{VI}

Qual o alcance das elaboraçóes e propostas analítico-interpretativas de Freyre tratadas neste artigo? Seriam datados os seus horizontes intelectuais e obsoletas as suas formulaçóes? Ou seria possível identificar convergências com reflexóes teóricas contemporâneas igualmente dedicadas a interpelar o imaginário da modernidade? A bem da verdade, o eventual legado de Freyre como um intelectual crítico da modernidade não passou despercebido por analistas recentes. Conforme assinalei anteriormente, Schneider (2012, p. 77 e 86) argumenta que embora variada e multifacetada, sua obra "comporta um traço recorrente, marcado pela crítica à modernidade ocidental”, que inclusive o teria levado a retratar a América Latina como novo paradigma de convivência humana. Por sua vez, Crespo (2003, p. 191-192) sustenta que um dos objetivos almejados por Freyre com a criaçáo dos estudos tropicológicos teria sido justamente "consolidar a cultura ibérica frente às culturas europeias dominantes e à paulatina hegemonia norte-americana sobre o mundo". Nessa direção, Freitas (2013, p. 10) argumenta que Freyre deliberadamente realizou "uma inversão da concepção de progresso moderno, ao considerar fracassado o modelo de trabalho de países desenvolvidos", apontando a experiência ibero-americana como "alternativa de processo civilizador". De maneira análoga, Baggio (2012, p. 120) entende que, ao contrapor a "cultura pan-hispânica” à norte-europeia, Freyre desejava apresentar a América tropical como "o lugar onde uma alternativa civilizatória poderia vicejar". Por fim, sugere-se que Freyre poderia "até ser descrito não somente como um pensador pós-moderno, mas também como pensador pós-colonial [...]” (BURKE; 
PALLARES-BURKE, 2009, p. 304), na medida em que oferecia "uma crítica da razão e da modernidade européias de um ponto de vista tropical" (BURKE; PALLARES-BURKE, 2009, p. 293-294) ${ }^{20}$.

De fato, ainda que, com o passar do tempo, várias de suas âncoras explicativas e interpretativas tenham sido deslegitimadas ou de todo abandonadas no seio das ciências sociais (caso, por exemplo, da adoçáo do ambiente natural como variável independente da experiência social), há evidências de que o teor de algumas das propostas de Freyre acerca da América Latina e de seu lugar na modernidade preserva certa ressonância intelectual com formulaçóes contemporâneas. Nesse exato sentido, parece haver indisfarçáveis convergências com agendas de reflexáo recentes no seio da teoria social inclinadas a estabelecer um diálogo crítico com o imaginário da experiência moderna. Refiro-me, nesse último caso, a trabalhos vinculados aos programas das modernidades múltiplas (EISENSTADT, 2000; 2010; GÖLE, 2000; WITTROCK, 2000), da modernidade global (DOMINGUES, 2003; DIRLIK, 2003; SCHMIDT, 2012), da condição pós-colonial (BHABHA, 2010; CHAKRABARTY, 2000; CHATERJEE, 2008), e da decolonialidade do saber/poder (DUSSEL, 2005; QUIJANO, 2005; MIGNOLO, 2005). Note-se que as propostas da abordagem das modernidades múltiplas caminham no sentido de problematizar a expectativa de que "o programa cultural da modernidade tal qual ele se desenvolveu na Europa e as constelaçôes institucionais básicas que lá emergiram, em última instância, predominariam em todas as sociedades em modernização e modernas [...]" (EISENSTADT, 2000, p. 1). Já trabalhos realizados sob a rubrica da modernidade global sustentam que, embora o centro da modernidade tenha sido "originalmente o Ocidente, em termos tanto de sua dinâmica quanto, em especial, de poder" (DOMINGUES, 2003, p. 251), estaríamos desautorizados a "tratar a Europa e a América do Norte como sinônimos da modernidade". Mutatis mutandis, à proporção que "a modernidade se torna global", algo similar deveria "ocorrer com a sociologia da modernidade." (SCHMIDT, 2012, p. 6).

20 Eis, para Burke e Pallares-Burke (2009, p. 305-306), "Quatro analogias ou afinidades entre as idéias de Freyre e aqueles teóricos pós-coloniais": a) "seu interesse de sempre com o subalterno assim como com o dominante"; b) "seu interesse em identidade cultural"; c) "sua preocupação com hibridismo, cultural e biológico", incluindo suas reflexões acerca da "hibridização de tradição e modernidade"; d) "sua crítica ao eurocentrismo", que o levava a tentar "pensar além do colonialismo". 
Mais radicais em seu enfrentamento com o imaginário da modernidade, elaboraçôes em torno da condição pós-colonial denunciam o "historicismo" que o subjaz, isto é, certa "ideologia do progresso", que faz do tempo histórico "uma medida da distância cultural" em virtude da qual o Ocidente e o não-Ocidente são dispostos em estágios ou momentos distintos de realização (CHAKRABARTY, 2000: 7; BHABHA, 2010; HALL, 2011). Já no programa da decolonialidade do saber/poder, a crítica da experiência da Europa ocidental como "a unica perspectiva que tem o privilégio de possuir categorias dominantes de pensamento a partir das quais e de onde o resto do mundo pode ser descrito, classificado, entendido e 'melhorado" (MIGNOLO, 2005, p. 36. Em itálico no original) avança no sentido de reivindicar legitimidade a "diferentes localidades de entendimento e produçáo do conhecimento" (MIGNOLO, 2005, p. 13-14). Nesse registro, experiências subalternas e fronteiriças (caso, por exemplo, de segmentos das sociedades latino-americanas) passam a ser concebidas como co-originárias bem como protagonistas da modernidade (QUIJANO, 2005).

Ora, é indisfarçável o ceticismo de Freyre, quando não sua profunda resistência, às reivindicaçóes universalistas de diagnósticos, conceitos e noçóes a seu ver unilateralmente forjados por norte-europeus e americanos anglo-saxônicos, à imagem e semelhança de realidades (sociais e ambientais) tomadas por exclusivas à Europa setentrional e à América do Norte. Nesse sentido, seu esforço de reabilitação do trópico e de seu clima quente, do hispano - segundo ele, há "séculos vítima das projeçôes das apologéticas realizaçôes em torno de outras civilizaçóes européias [...]" (FREYRE, 1975a, p. 65) -, do mestiço e de seus hábitos (FREYRE, 1975a, p. XXXIII-XXXIV) consistia justamente numa tentativa de denunciar aquela unilateralidade travestida de universalismo. Ademais, é clara sua recusa às expectativas de convergência subjacentes às teorias da modernização: a seu ver, ao invés de simples replicação da experiência norte-europeia (e, posteriormente, norte-americana), as transformaçóes por que passavam as sociedades latino-americanas desde o século XIX estariam resultando em cenários novos, singulares, sob o impacto decisivo de especificidades culturais, históricas e ambientais irredutíveis a outros contextos.

Quanto aos estereótipos que normalmente pesavam sobre as sociedades erigidas desde a colonização europeia em espaços tropicais, Freyre argumentava que eles advinham do fato do controle europeu sobre as "regióes boreais e 
temperadas" da América ter ocorrido num curto espaço de tempo, sem qualquer modificação profunda dos "valores e estilos de vida" do colonizador norte-europeu (FREYRE, 1975a, p. 27). Daí a associação imagética da selva ao continente americano ter se restringido cada vez mais às sociedades constituídas nos trópicos. Ato contínuo, cedo também se cristalizou a imagem de que a outra face da exuberância e desordem da vegetação tropical era a incivilidade de suas formas de vida humana - e, consequentemente, a impossibilidade de "uma nova cultura humana nos países tropicais e quase tropicais da América" (FREYRE, 1975a, p. 27). Retratado como uma "natureza bruta incapaz de tornar-se integralmente mundo histórico ou civilizado", o trópico seria, conforme esse ideário refutado por Freyre, um "espaço onde a cultura humana, sufocada pela constância da presença dessa natureza ou dessa selva exuberante, turbulenta e absorvente, dificilmente se tornará civil ou civilizada no sentido mais alto e mais puro da expressão " (FREYRE, 1975a, p. 28-29). Em seu entendimento, o problema estava no fato de que ao cabo dessas construçóes mentais, a Europa setentrional consolidava-se indevidamente como padrão de medida geral: a atitude de exotização do "Outro" (leia-se, do trópico e de suas gentes) amparava-se no mito de uma "presumida normalidade européia de comportamento", à qual se contrastavam "presumidos desvios dessa normalidade representados pelo comportamento, quer dos náo-europeus nativos e habitantes de espaços tropicais, quer dos europeus que se deseuropeizaram, tropicalizando-se pela residência longa no trópico e através da adoção de estilos tropicais de vida" (FREYRE, 1975a, p. 81). De tudo isso resultaria a imagem conforme a qual existiria um e apenas um "sentido europeu de civilidade e de civilização" (FREYRE, 1975a, p. 29).

Esse empreendimento crítico teve importantes desdobramentos no tratamento dedicado pelo autor às noçóes de tempo e espaço (BURKE; PALLARES-BURKE, 2009, p. 292-296). Com efeito, a inexorabilidade e aplicabilidade universal de uma concepção linear, horizontal, vazia e abstrata do espaço-tempo não encontra lugar nas considerações de Freyre acerca da experiência latino-americana. Diante do dilema de "ser ou não a variedade 'Ocidental' a única forma possível de civilização geral” (FREYRE, 1975a, p. 84), Freyre preferia denunciar o provincianismo de modelos unilineares de desenvolvimento societário aplicados à modernidade. Muito distante da imagem de um espaço esvaziado e de-substancializado, apartada de predicados tangíveis, o 
autor elevava qualidades específicas atribuídas aos trópicos à condição de fatores condicionantes de primeira linha nas experiências societárias da América Latina. Ademais, na contramáo da ideia de um tempo abstrato, padronizado e progressivo, Freyre queria nos fazer ver que, da mesma forma que inexiste "um tempo só vivido de modo unilinear pelo indivíduo; e sim vários tempos, variamente, contraditoriamente, vividos por ele", também as "relações sociedade-cultura-tempo" seriam marcadas por cruzamentos e intersecçóes diversas (FREYRE, 1973b, p. 109-110).

Tais formulaçôes levaram-no até mesmo a questionar o pioneirismo exclusivo na formação da modernidade comumente atribuído à Europa do norte (FREYRE, 1975b) ${ }^{21}$. Sendo várias as origens da modernidade bem como múltiplas suas linhas de desenvolvimento, as experiências latino-americanas poderiam, então, ser vistas de um novo ângulo, para além do diagnóstico da "falta" e da "incompletude": desde a assimilação da civilização europeia ao sistema cultural-ecológico do trópico, estaria emergindo uma "terceira situação", a qual não deveria ser definida nem como "subeuropéia", nem como "antieuropéia". Fundamental acerca dessa "terceira situação" é que, ao invés de ensaio ou cópia imperfeita de outra civilização (pretensamente) superior, a América Latina se lhe mostrava "uma prova mesmo, da capacidade de um grupo de povos largamente nãoeuropeus em sua composição étnica e na parte folclórica da sua cultura em crescer como um conjunto de civilizaçóes modernas" (FREYRE, 2000b, p. 266), e, como tais, "em se organizarem como naçóes de tipo moderno em espaços semi ou totalmente tropicais" (idem). Assim compreendido, o desenvolvimento extraeuropeu de um complexo hispânico representava nada menos que o falseamento da tese conforme a qual civilizaçóes mistas, com suas populaçóes mestiças, eram "incapazes de competir, em virtudes criadoras, com as civilizaçóes chamadas puras e com as raças também intituladas puras [...]." (FREYRE, 1975a, p. 109).

Sempre se valendo daquela estratégia, pela qual as pretensas especificidades hispânicas e latino-americanas sáo cotejadas e confrontadas com as experiências norte-europeias e americanas setentrionais, um dos últimos e quiçá

2I Nessa direção, embora reconhecesse o descompasso entre os hispanos e o chamado "ritmo da Revolução Industrial", Freyre argumentava que "as atividades espanholas e portuguesas na Ásia, África e América tornaram possivel esse novo tipo de produção industrial ao dar ao capitalismo europeu e ao industrialismo burguês, material para a manufatura em uma nova escala e num novo ritmo [...]" (FREYRE, 1975b, p. 135). 
mais ousados lances de Freyre nessa batalha argumentativa consistiu em inverter aquela imagem especular cara ao imaginário da modernidade: dessa vez não as ditas "sociedades centrais", mas as sociedades americanas erigidas em ambientes tropicais deveriam ser tomadas como modelares; delas adviriam soluçóes criativas e eficazes aos problemas sociais de nossos tempos. A seu ver, as sociedades mais industrializadas estavam passando por mudanças significativas; o desenvolvimento tecnológico e a automação vinham criando as condiçôes de possibilidade para "novos tipos de economia e de convivência humana" (FREYRE, 1975a, p. XXXIX), as quais se refletiam num "tempo crescentemente desocupado, criado pela mecanização do trabalho" (FREYRE, 1973b, p. 108). Ocorre que, nessa escalada, "o capitalismo industrialista, sob a mística do 'tempo é dinheiro" teria cometido excessos ao atribuir exagerada importância tanto ao sentido cronométrico como ao monetário do tempo" (FREYRE, 1973b, p. 121). Esse cenário, que o autor chegou a chamar de "pós-moderno", seria palco de uma verdadeira "revoluçáo biossocial em começo". Em meio ao aparecimento desses novos desafios e problemas, dentre os quais "o da organização do trabalho, o dos sindicatos de atividades operárias - problemas relacionados com o tempo ocupado [...]" (FREYRE, 1973b, p. 108), tal "revolução" estaria a nos conduzir "para uma total e definitiva desmoralização, quer do capitalismo ortodoxo, quer dos seus opositores" (sendo os mais ostensivos "o Comunismo, o Sindicalismo, o Laborismo, o Trabalhismo") - todos "vindos da época por excelência do tempo-dinheiro e do tempo-trabalho" (FREYRE, 1973b, p. 22). A saúde e a criatividade dessas sociedades demandavam urgentemente a adoção de medidas corretivas, quando não mudanças mais substantivas.

Note-se que, no entendimento de Freyre, esse cenário "pós-moderno" reclamava justamente a restauração do "prestígio do ócio" em oposição ao negócio, ou seja, a restauração da "relação do Homem com o Tempo em termos menos de produtividade de trabalho individual ou grupal que de capacidade do desocupado - indivíduo ou grupo - para preencher o tempo desocupado ou livre de modo diversamente lúdico, hedônico e em alguns casos, criador ou sublimador [...]" (FREYRE, 1973b, p. 108). Nessas circunstâncias, os "supostos arcaísmos" comumente atribuídos aos hispanos reapareceriam "hoje, como corretivos, que tendem a acentuar-se em saberes pós-modernos já presentes nos apenas modernos" (FREYRE, 1973b, p. 11). Seus valores, fortalecidos ainda mais com a aventura colonizadora dos trópicos, "pouco estimados e 
até subestimados e mesmo negados durante os dias de estabilidade triunfal da civilização capitalista e econômica e politicamente liberal nas suas formas ortodoxas", hoje poderiam enfim ser resgatados (FREYRE, 2003b, p. 43-44). O atraso tecnológico dessas sociedades seria compensado pelo fato de disporem "de vastas reservas de cultura folclórica, dentro da qual se conservam danças, músicas, jogos, saudáveis tanto do ponto de vista sociológico como do ponto de vista médico" (FREYRE, 1973b, p. 116). Ou seja, exatamente "a maior integração de hispanos que de norte-europeus, nos trópicos", outrora vista como empecilho a sua entrada plena na modernidade, parecia a Freyre "reabilitar o trópico como espaço susceptível de servir de ambiente a civilizaçóes não apenas modernas, mas pós-modernas [...]" (FREYRE, 1975a, p. XXXIII). Por todas essas razóes, estaríamos diante de "um paradoxo que é o da América Latina tornar-se de repente, sob certos aspectos, pós-moderna e a América de língua inglesa, arcaica em suas atitudes e em seus hiatos, criados por três séculos de progresso à base de um sentido apenas econômico de tempo: o de tempo-dinheiro" (FREYRE, 2003a, p. 28).

Ora, guardadas as irredutíveis especificidades de cada um daqueles programas contemporâneos de reflexáo supracitados e dos contextos particulares em que se constituíram, entendo haver um denominador comum a eles, que em certa medida também converge com as proposiçóes de Gilberto Freyre acerca da experiência societária da América Latina: 1) observa-se, em comum, um esforço de problematização das referências espaço-temporais sobre as quais se apoia certo imaginário da modernidade tido por hegemônico nas ciências sociais e para além delas; 2) embora com graus distintos de profundidade, inquire-se a validade científica de algumas das categorias, conceitos e noçóes desse imaginário e de seus reflexos no discurso sociológico da modernidade; 3) ademais, há convergências no sentido de serem levantadas contraevidências ao escopo de aplicação empírico pretendido pelas categorias e noçôes desse discurso sociológico; 4) além disso, desafia-se as insinuaçóes prescritivas que esse discurso projeta sobre sociedades retratadas como configuraçóes não plenamente realizadas da experiência moderna (Tavolaro, 2014); e, por fim, 5) Freyre e essas abordagens compartilham o esforço de conferir protagonismo a cenários e agentes com frequência tidos por replicadores tardios, incompletos ou inautênticos da modernidade. Tais convergências parecem-me um forte sinal de que ao menos algumas das formulaçóes de Freyre críticas ao imaginário da modernidade resistiram à passagem do tempo. 
Reconhecidos esses pontos de contato, resta a questão: até que ponto Freyre é plenamente exitoso em seu intento de apresentar as experiências latino-americanas como uma alternativa societária no concerto da modernidade? Mignolo (2005, p. 67) alude a certa ideia de América Latina cultivada por elites do subcontinente a partir do século XIX que, mesmo em busca de uma identidade própria, abraçaram a "ideologia da França” na mesma proporção em que "deram as costas aos indígenas e negros" - esquecendo-se, assim, dos "legados de sua própria consciência crítica". Ora, esse não parece ter sido o caso da retórica freyreana. Larreta e Giucci (2007, p. 423) certa feita argumentaram que Freyre pretendia examinar a modernidade da cultura brasileira "em pé de igualdade com centros hegemônicos". De fato, tudo leva a crer que essa também era a sua ambição em relação à experiência latino-americana. Mas, em minha interpretação, tal pretensão viu-se em alguma medida frustrada. A razão disso não parece estar em sua conhecida valorização da tradição (BASTOS, 2006; PALLARES-BURKE, 2005; VILLAS-BÔAS, 2006), em seu alardeado conservantismo político, ou mesmo em uma pretensa falta de "consciência da situação pós-colonial e neo-colonial" (VALENTE, 2013, p. 113). O problema é de outra ordem, em parte suscitado por Larreta e Giucci quando defendem que a adesão de Freyre ao "vocabulário das ciências sociais modernas o torna propenso a pensar as diversas culturas em termos de adiantadas e atrasadas" (LARRETA; GIUCCI, 2007, p. 465). Ora, para que Freyre lograsse consumar aquele objetivo seria preciso, acima de tudo, desmontar por completo estigmas e estereótipos que, conforme ele mesmo se esforçou por salientar, desqualificavam ou desautorizavam a apresentação da experiência latino-americana como um cenário plenamente moderno. Ocorre que, e esse a meu ver é o calcanhar de Aquiles de seu projeto, o autor não consegue escapar de certa "ontologia" da América Latina (MIGNOLO, 2005): não são poucas as ocasióes em que seus retratos exotizam e essencializam as configuraçôes societárias da região, vinculando-as a condiçôes tomadas como únicas e exclusivas de suas gentes, culturas e lugares. Isso o leva inadvertidamente a reproduzir aquela imagem das sociedades latino-americanas como desvios das "sociedades modernas centrais". Dessa feita, conquanto se possa falar que Freyre esboça uma narrativa contra-hegemônica da modernidade, suas formulaçóes não parecem exaurir todas as suas implicaçóes críticas. 


\section{Referências}

ALEXANDER, J. "The centrality of the classics". In: GIDDENS, A.; TURNER, J. (Eds.). Social theory today. Stanford: Stanford University Press, 1987.

ANDERSON, B. Imagines communities. London: Verso, 1991.

ARAÚJO, R. B. Guerra e paz: Casa-Grande \& Senzala e a obra de Gilberto Freyre nos anos 30. Rio de Janeiro: Editora 34, 1994.

BALLESTRIN, L. "América Latina e o giro decolonial". Revista brasileira de ciência política, v. 11, p. 89-117, 2013.

BAGGIO, K. G. "Iberismo, hispanismo e latino-americanismo no pensamento de Gilberto Freyre”. Investigaciones socio históricas regionales, Año 2, n. 2, p. 109-131, 2012.

BASTOS, E. R. "Iberismo na obra de Gilberto Freyre”. Revista USP, v. 38, p. 48-57, jun./ ago. 1998a.

As criaturas de prometeu: Gilberto Freyre e a formação da sociedade brasileira. São Paulo: Global, 2006.

"Atualidade do pensamento social brasileiro". Sociedade e estado, v. 26, n. 2, p. 51-70, 2011.

BENJAMIN, W. "Sobre o conceito da história". Magia e técnica, arte e política: ensaios sobre literatura e história da cultura. São Paulo: Editora Brasiliense, 1993.

BETHELL, L. "O Brasil e a idéia de 'América Latina' em perspectiva histórica”. Estudos históricos, n. 44, p. 289-321, 2009.

BHABHA, H. O local da cultura. Belo Horizonte: Ed. UFMG, 2010.

BOMFIM, M. A América Latina: males de origem. Rio de Janeiro: Topbooks, 1993.

BURKE, P.; PALLARES-BURKE, M. L. Repensando os trópicos: um retrato intelectual de Gilberto Freyre. São Paulo: Editora Unesp, 2009.

CHAKRABARTY, D. Provincializing Europe: Postcolonial thought and historical difference. Princeton: Princeton University Press, 2000.

CHATTERJEE, P. La nación en tiempo heterogêneo: y otros estúdios subalternos. Buenos Aires: Siglo XXI Editores, 2008. 
CRESPO, R. A. "Gilberto Freyre e suas relaçôes com o universo cultural hispânico". In: Kosminsky, E. V., Lépine, C., Peixoto, F. A. (Orgs.). Gilberto Freyre em quatro tempos. Bauru: Edusc; São Paulo: Ed. Da Unesp, 2003.

DOMINGUES, J. M. Do ocidente à modernidade: intelectuais e mudança social. Rio de Janeiro: Civilização Brasileira, 2003.

DUSSEL, E. "Europa, modernidade e eurocentrismo". In: LANDER, E. (Org.). A colonialidade do saber: eurocentrismo e ciências sociais. Buenos Aires: CLACSO, 2005.

EISENSTADT, S. N. "Multiple modernities". Daedalus, v. 129, n. 1, p. 1-29, 2000.

"Modernity and modernization". Sociopedia.isa, International Sociological Association, p. 1-15, 2010.

FERES Jr., J. A história do conceito de 'Latin America' nos Estados Unidos. Bauru: Edusc, 2005.

FREYRE, G. Regiáo e tradiçãa. Rio de Janeiro: Livraria José Olympio Editora, 1941.

_. Sociologia: introdução ao estudo dos seus princípios. Rio de Janeiro: José Olympio, 1973a.

Além do apenas moderno. Livraria José Olympio Editora, $1973 \mathrm{~b}$.

O brasileiro entre os outros hispanos: afinidades, contrastes e possíveis futuros nas suas inter-relaçóes. Rio de Janeiro: J. Olympio/Brasília: Instituto Nacional do Livro, 1975a.

[1963]. "On the Iberian concept of time". In: O brasileiro entre os outros hispanos: afinidades, contrastes e possíveis futuros nas suas inter-relaçóes. Rio de Janeiro: J. Olympio/ Brasília: Instituto Nacional do Livro, 1975b.

. Manifesto regionalista. Maceió: Ed. Ufal, 1976.

[1936]. Sobrados e mucambos: história da sociedade patriarcal no Brasil. Rio de Janeiro: Record, 1996.

- [1933]. Casa-grande \& senzala: introdução à história da sociedade patriarcal no Brasil. Rio de Janeiro: Record, 2000a.

. [1963/1971]. Novo mundo nos trópicos. Rio de Janeiro: Topbooks, 2000 b.

[1945]. Interpretação do Brasil: Aspectos da formação social brasileira como processo de amalgamento de raças e culturas. São Paulo: Companhia das Letras, 2001. 
[1963]. "Americanidade e Latinidade da América Latina: crescente interpenetração e decrescente segregação". In: Americanidade e latinidade da América Latina e outros textos afins. Brasília: Ed. UnB/São Paulo: Imprensa Oficial do Estado, 2003a, p. 17-34. [1942]. "A propósito da política cultural do Brasil na América". In: Americanidade e latinidade da América Latina e outros textos afins. Brasília: Ed. UnB/São Paulo: Imprensa Oficial do Estado, 2003b, p. 35-46.

[1942]. "Interamericanismo". In: Americanidade e latinidade da América Latina e outros textos afins. Brasília: Ed. UnB/Sáo Paulo: Imprensa Oficial do Estado, 2003c, p. 47-51.

[1942]. "Americanismo e hispanismo". In: Americanidade e latinidade da América Latina e outros textos afins. Brasília: Ed. UnB/São Paulo: Imprensa Oficial do Estado, 2003d, p. 91-94.

[1937]. Nordeste: aspectos da influência da cana sobre a vida e a paisagem do Nordeste do Brasil. São Paulo: Global, 2004.

. [1961]. O luso e o trópico. São Paulo: É Realizaçôes, 2010.

GÖLE, N. “Snapshots of Islamic modernities”. Daedalus, v. 129, n. 1, p. 91-117, 2000.

HALL, S. Da diáspora: identidades e mediaçóes culturais. Belo Horizonte: Ed. UFMG, 2011. HARVEY, D. The condition of postmodernity: an enquiry into the origins of cultural change. Cambridge: Blackwell, 1995.

HEGEL, F. The philosophy of history. New York: Dover Publications Inc., 1956.

HOLANDA, S. B. Raízes do Brasil. Rio de Janeiro: José Olympio Editora, 1994.

LARRETA, E.; GIUCCI, G. "Prefácio". In: Americanidade e latinidade da América Latina e outros textos afins. Brasília: Ed. UnB/São Paulo: Imprensa Oficial do Estado, 2003, pp. $9-15$.

LARRETA, E.; GIUCCI, G. Gilberto Freyre: uma biografia cultural: A formação de um intelectual brasileiro: 1900-1936. Rio de Janeiro: Civilização Brasileira, 2007.

LIMA, M. O. América Latina e América Inglesa. Brasília: Senado federal, Conselho Editorial, 2010.

MAIA, J. M. "Pensamento brasileiro e teoria social: notas para uma agenda de pesquisa". Revista brasileira de ciências sociais, v. 24, n. 71, p. 155-168, 2009. 
MIGNOLO, W. Local histories/global designs: Coloniality, subaltern knowldges, and border thinking. Princeton: Princeton University Press, 2000a.

"(Post)Occidentalism, (Post)Coloniality, and (Post)Subaltern rationality". In: AFZAL-KHAN, Fawzia and SESHADI-CROOKS, Kalpana (Eds). The pre-occupation of postcolonial studies. Durham \& London: Duke University Press, 2000b.

The idea of Latin América. Oxford: Blackwell, 2005.

NABUCO, J. "Balmaceda - Post-scriptum: a questão da América Latina”. In: Essencial Joaquim Nabuco. São Paulo: Penguin Classics Cia. das Letras, 2010a.

"A parte da América na civilização". In: Essencial Joaquim Nabuco. São Paulo: Penguin Classics Companhia das Letras, 2010b.

"A aproximação das duas Américas". In: Essencial Joaquim Nabuco. São Paulo: Penguin Classics Companhia das Letras, 2010c.

PALLARES-BURKE, M. L. Gilberto Freyre: um vitoriano dos trópicos. São Paulo: Editora da UNESP, 2005.

PRADO Jr., C. Formação do Brasil Contemporâneo. São Paulo: Cia. das Letras, 2011.

QUIJANO, A. “Colonialidade do poder, eurocentrismo e América Latina”. In: LANDER, E. (Org). A colonialidade do saber: eurocentrismo e ciências sociais. Buenos Aires: CLACSO, 2005.

SANTOS, A. C. As naturezas de Freyre: natureza e ecologia em "Nordeste" (1937) de Gilberto Freyre. Dissertação (Mestrado em Sociologia) - IFCH/UNICAMP, 2008.

SCHMIDT, V. "Conceptualizing Global Modernity: A tentative sketch". Working paper series, Sociology Department, National University of Singapore, 2012.

SCHNEIDER, A. L. "Iberismo e luso-tropicalismo na obra de Gilberto Freyre". História da historiografia, n. 10, p. 75-93, 2012.

TAVOLARO, S. B. F. "Gilberto Freyre e nossa 'Modernidade Tropical': entre a originalidade e o desvio". Sociologias, v. 15, n. 33, p. 282-317, 2013.

"A tese da singularidade brasileira revisitada: desafios teóricos contemporâneos".

Dados: Revista de ciências sociais, v. 57, n. 3, p. 633-673, 2014.

VALENTE, L. F. “Americanidade e Latinoamericanidade na obra de Gilberto Freyre”. Antares: letras e humanidades, v. 5, n. 10, p. 105-114, 2013. 
VILLAS-BÔAS, G. Mudança provocada: passado e futuro no pensamento sociológico brasileiro. Rio de Janeiro: Editora FGV, 2006.

WITTROCK, B. "Modernity: one, none, or many? European origins and modernity as a global condition”. Daedalus, v. 129, n. 1, p. 31-60, 2000.

\section{Outras fontes:}

BASTOS, E. R. "Os autores brasileiros e o pensamento hispânico". XXII ENCONTRO ANUAL DA ANPOCS. Anais... out. 1998b. Disponível em: <http://portal.anpocs.org/ portal/index.php?option=com_docman\&task=doc_view\&gid=5111\&Itemid=359>. Acesso em: 15 ago. 2014.

FREITAS, I. M. "A Brasil e as Américas em Gilberto Freyre: das veias abertas pela colonização aos veios abertos para o futuro". XXIX CONGRESSO LATINOAMERICANO DE SOCIOLOGIA. Anais... 2013. Disponível em: <http://actacientifica.servicioit.cl/biblioteca/ gt/GT17/GT17_MendesFreitas.pdf>. Acesso em: 20 ago. 2014.

FREYRE, G. Atualidade de Euclydes da Cunha. Conferência lida em 29/10/1940. Disponível em: <http://prossiga.bvgf.fgf.org.br/portugues/obra/opusculos/atualidade_euclides.htm>. Conferência lida em 29/10/1940. Acesso em:17 fev. 2012.

\section{Images of Another Modernity: Gilberto Freyre and the Latin American space-time}

\section{Abstract}

Time and space are two key categories in Gilberto Freyre's intellectual program. Keeping in mind his most renown and celebrated work on the Brazilian social formation, this article seeks to identify the meanings and connotations that Freyre attributes to both notions while coming to grips with the place and importance of Latin America in modernity. As I intend to demonstrate, for Freyre the Latin American time-space configuration was irreducible to that of the so-called central modern societies, both on the conceptual level and on the level of everyday experience, which in and of itself is said to account for the peculiar patterns of sociability found in one and other societal contexts. Last but not least, the article aims at investigating the occasional existence of convergences between Freyre's research agenda and a set of contemporary approaches that have emerged in sociological theory in recent times.

Keywords: Modernity. Gilberto Freyre. Sociological theory. Brazilian social thought.

Recebido em 20/02/2016

Aceito em 10/11/2016 